\title{
A Rare Neoplastic Growth on the Ear Lobe
}

\section{Neobvyklá nádorová infiltrace ušního lalůčku}

\author{
Rovere R. K. ${ }^{1}$, Hilgert S. F. ${ }^{2}$, da Costa Camara P. ${ }^{3}$, de Lima A. S. ${ }^{4}$ \\ 'Department of Medical Oncology, Santo Antonio Hospital, Blumenau, Santa Catarina, Brazil \\ 2 Santo Antonio Hospital, Blumenau, Santa Catarina, Brazil \\ ${ }^{3}$ Department of Surgical Oncology, Santo Antonio Hospital, Blumenau, Santa Catarina, Brazil \\ ${ }^{4}$ Private Practice of Dermatology, Brusque, Santa Catarina, Brazil
}

\begin{abstract}
Summary
We report a case of an 83-year-old previously healthy female patient presenting with a swiftly evolving erythematous violaceous, infiltrative, ulcerated onion-like mass with hyperkeratotic surface on the left ear lobe. The lesion was excised and resulted as an atypical fibroxanthoma, an extremely rare neoplastic growth, being a superficial variant of pleomorphic malignant fibrous histiocytoma. A brief review of diagnosis, treatment and prognosis is discussed.
\end{abstract}

\section{Key words}

skin - clear cell atypical fibroxanthoma - immunohistochemistry - differential diagnosis - head and neck neoplasms - neoplasms - prognosis

\section{Souhrn}

Prezentujeme případ 83leté ženy, dosud bez závažných onemocnění, u které byla zjištěna rychle rostoucí, zarudlá nafialovělá infiltrace levého ušního lalůčku, s hyperkeratotickým povrchem cibulovitého vzhledu a ojedinělou ulcerací. Po odstranění byla léze diagnostikována jako atypický fibroxanthom - zcela ojedinělý tumor představující kožní variantu maligního fibrózního histiocytomu. Článek v krátkosti popisuje diagnostiku, terapii a prognózu onemocnění.

\section{Klíčová slova}

kůže - světobuněčný atypický fibroxanthom - imunohistochemie - diferenciální diagnóza nádory hlavy a krku - novotvary - prognóza

\section{Case report}

An 83-year-old previously healthy female patient, agriculturist, presents with a history of an erythematous violaceous infiltrative, ulcerated onion-like mass with hyperkeratotic surface on the left ear lobe (Fig. 1-4). As the patient had a long history of chronic sun exposure and lived in one of the highest melanoma rates areas in the world [1], it was initially thought to be a metastatic melanoma by the surgeon.

The lesion was then completelly excised and sent for pathological analysis, with the result coming as a malignant ulcerated fusocellular neoplasia with negative margins. Further, an immuno- histochemical analysis was performed and was negative for all markers, including protein S 100, all the cytokeratins, Melan A/MART 1, protein p53, CD 23 and desmin, compatible with an atypical fibroxanthoma, a very rare form of skin cancer. The atypical fibroxanthoma is a superficial variant of pleomorphic malignant fibrous histiocytoma [2]. Our case has followed the classic presentation as a head and neck tumor in an elderly individual, and to the best of our knowledge just one case in medical literature has been reported in a different topography-on the dorsum of the hand, described almost three decades ago [3].

\author{
The authors declare they have no potential \\ conflicts of interest concerning drugs, \\ products, or services used in the study. \\ Autor̆i deklarují, že $v$ souvislosti s předmětem \\ studie nemaji žádné komerční zájmy. \\ The Editorial Board declares that the manuscript \\ met the ICMJE "uniform requirements" for \\ biomedical papers. \\ Redakční rada potvrzuje, že rukopis práce \\ splnil ICMJE kritéria pro publikace zasílané do \\ biomedicínských časopisů.

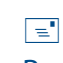 \\ Rodrigo Kraft Rovere, MD \\ Oncology Unit \\ Santo Antonio Hospital \\ Rua Itajai 545 \\ Blumenau, Santa Catarina \\ CEP 89050100 Brazil \\ e-mail: rodrigorovere@hotmail.com
}

Submitted/Obdrženo: 31. 3. 2014

Accepted/Prijiato: 1. 4. 2014

http://dx.doi.org/10.14735/amko2014367

In a retrospective analysis of Mohs surgery, only $0.2 \%$ of the malignant findings were fibroxantomas out of 42,279 patients [4].

\section{Conclusion}

Atypical fibroxanthoma normally appears as a swiftly growing nodular or nodulo-ulcerative lesion. It may be composed predominantly of either pleomorphic, spindle, epithelioid cells, or a mixture of these cells. The differential diagnosis includes pleomorphic dermal sarcoma, squamous cell carcinoma, malignant melanoma and leiomyosarcoma [5].

It occurs mostly in older adults and in sun exposed areas [6], with male pre- 


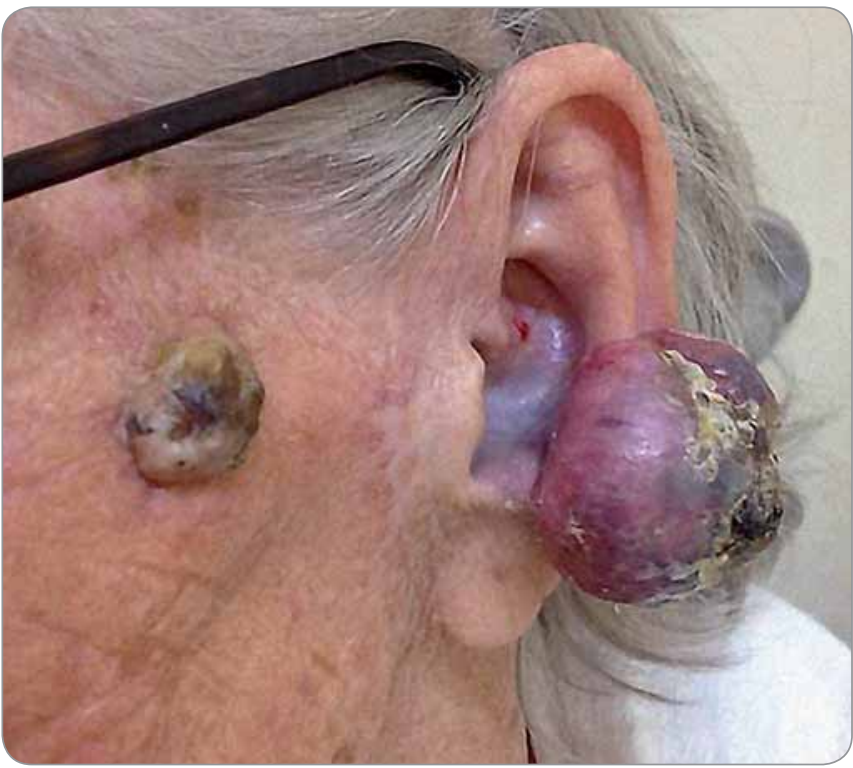

Fig 1. A solitary erythematous nodule with hyperkeratotic and ulcerated surface on the left ear lobe (front view).

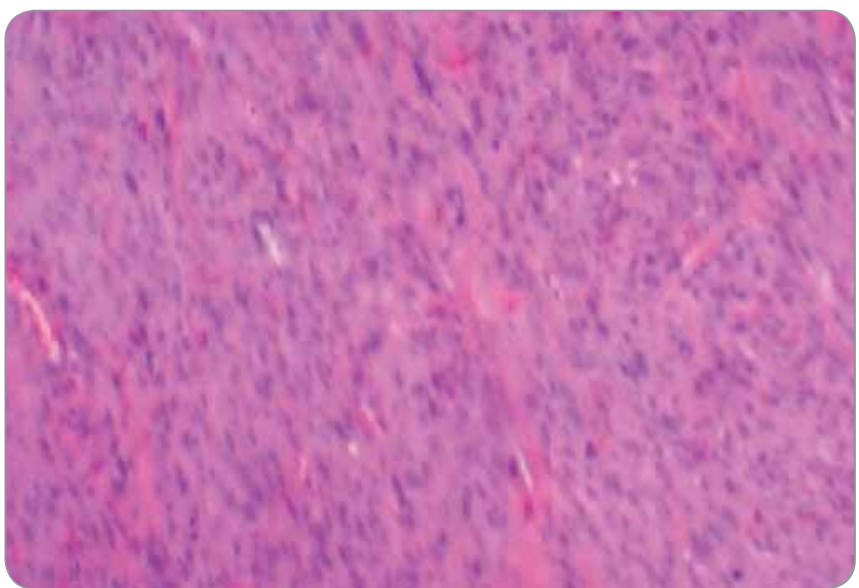

Fig. 3. Fusocelular proliferation in multi-directional bundles (100x).

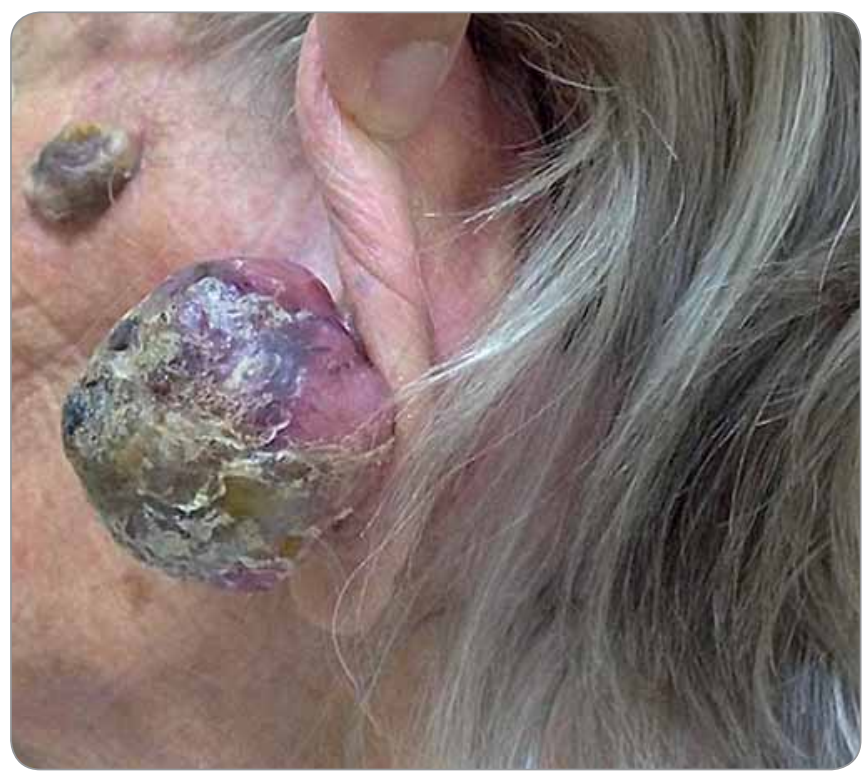

Fig. 2. A solitary erythematous nodule with prominent vessels, hyperkeratotic and ulcerated surface on the left ear lobe (side view).

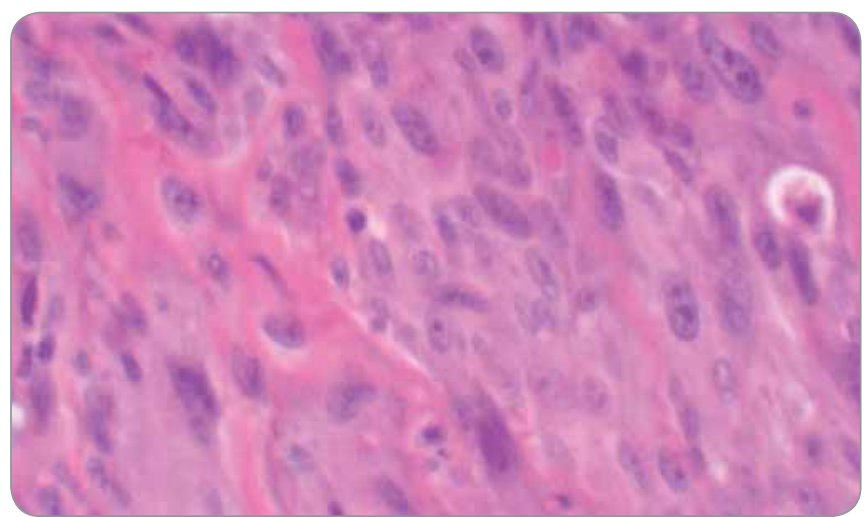

Fig. 4. Proliferation of elongated cells with poorly defined limits, dense eosinophilic cytoplasm, vesiculous or dense nuclei, irregular nuclear membrane and small to moderate diameter variation (400x). dominance [7] and is a diagnosis of exclusion. The treatment is surgical and the preferred method is the aforementioned Mohs surgery [8]. Even though fibroxanthoma may be locally aggressive [9], the prognosis is usually very good if margins are adequate and these tumors rarely metastasise $[7,10]$.

\section{References}

1. Naser N. Cutaneous melanoma: a 30-year-long epidemiological study conducted in a city in southern Brazil, from 1980-2009. An Bras Dermatol 2011; 86(5): 932-941.
2. Bedir R, Agirbas S, Sehitoglu I et al. Clear cell atypical fibroxantoma: a rare variant of atypical fibroxanthoma and review of the literature. J Clin Diagn Re 2014; 8(6): FD09-FD11. doi: 10.7860/JCDR/2014/8798 4466.

3. Patterson JW, Konerding H, Kramer WM. "Clear cell” atypical fibroxanthoma. J Dermatol Surg Oncol 1987; 13(10): 1109-1114.

4. Anderson $H L$, Joseph AK. A pilot feasibility study of a rare skin tumor database. Dermatol Surg 2007; 33(6): 693-696.

5. Hussein MR. Atypical fibroxanthoma: new insights. Expert Rev Anticancer Ther 2014; 14(9): 1075-1088.

6. Hammerschmidt M, Azevedo LM, Ruaro A et al. Case for diagnosis. Atypical fibroxanthoma. An Bras Dermato 2012; 87(4): 647-648.
7. Wollina U, Schonlebe J, Ziemer M et al. Atypical fibroxanthoma: a series of 56 tumors and an unexplained uneven distribution of cases in southeast Germany. Head Neck. In press 2014. doi: 10.1002/hed.23673.

8. McCoppin HH, Christiansen D, Stasko T et al. Clinical spectrum of atypical fibroxanthoma and undifferentiated pleomorphic sarcoma in solid organ transplant recipients: a collective experience. Dermatol Surg 2012; 38(2): 230-239. doi: 10.1111/j.1524-4725.2011.02180.x 9. Inskip M, Magee J, Weedon D et al. Atypical fibroxanthoma of the cheek-case report with dermatoscopy and dermatopathology. Dermatol Pract Concept 2014; 4(2): 77-80. doi: 10.5826/dpc.0402a16.

10. Cooper JZ, Newman SR, Scott GA et al. Metastasizing atypical fibroxanthoma (cutaneous malignant histiocytoma): report of five cases. Dermatol Surg 2005; 31(2): 221-225. 